\title{
ZVÝŠENIE INTERAKTIVITY A SKVALITNENIE PROCESU VÝUČBY V OBLASTI MECHANIZÁCIE A AUTOMATIZÁCIE PÔŠT FORMOU MULTIMEDIÁLNEJ E-APLIKÁCIE.
}

\author{
Peter Kolarovszki ${ }^{1}$
}

\section{1. Úvod}

Článok sa venuje problematike multimediálnych e-aplikácií, ktoré sú základom pre zvyšovanie interaktivity a $\mathrm{z}$ toho plynúce možne skvalitnenie vzdelávania $\mathrm{v}$ poštovom sektore. Je $\mathrm{v}$ ňom analyzované balíkové triediace zariadenie so sklopnými plošinkami. Nosnou čast'ou článku je popis ako aj postupnost' krokov k vytvoreniu multimediálnej eaplikácie pre mechanizované a automatizované spracovanie poštových zásielok. Na konkrétnom príklade je prezentovaný vznik multimediálnej e-aplikácie so všetkými výrazovými prostriedkami od modelovania 3D modelov pre animácie cez záznam a editáciu videa až po finálny export aplikácie. Je v ňom obsiahnuté zhodnotenie jednotlivých fáz tvorby a celkového návrhu aplikácie. Pre multimediálne spracovanie bolo vybraté balíkové triediace zariadenie so sklopnými plošinkami nachádzajúce sa na hlavnom spracovatel'skom stredisku HSS ZA 022.

\section{Spracovanie balíkov na HSS Žilina 022}

Vybrané balíky, ktoré sú adresované mimo vlastný doručovací obvod podacej pošty, sú spracované do záverov na poštovú prepravu do OSS. Po príchode a spracovaní týchto záverov v OSS sú balíky adresované mimo doručovací obvod OSS spracované do záverov pre príslušné HSS. V HSS sú závery triedené manuálne alebo pomocou balíkového triediaceho zariadenia.

Pred samotným triedením v HSS sa všetky balíky snímajú skenermi čiarových kódov pre aktualizáciu údajov v systéme Track \& Trace. Zosnímaním balíka sa uloží do systému čas jeho príchodu a tým sa zaistí to, že bol na HSS dopravený.

Po vyložení prepravných kontajnerov z poštového kurzu sa zásielky triedia v prekládke rozčlenenej do balíkovej triediarne a prekládky. V prekládke sa triedia zapísané a expresné zásielky a balíky nevhodné na triedenie balíkovým triediacim zariadením. V balíkovej triediarni sa triedia všetky balíky 1. a 2. triedy, ktoré sú vhodné na strojné triedenie ostatné sa d’alej triedia v prekládke. V balíkovej triediarni sa nachádza automatická triediaca linka so sklopnými plošinkami, ktorá bola nainštalovaná koncom roka 2009. Na obrázku 1. je zobrazený počet spracovaných balíkov za prvé tri mesiace v rokoch 2009 a 2010 na HSS Žilina 022. Rok 2009 popisuje „starý“ triedič z výhybkami od seba a rok 2010

\footnotetext{
${ }^{1}$ Ing. Peter Kolarovszki, PhD., Žilinská univerzita v Žiline, Fakulta prevádzky a ekonomiky dopravy a spojov, Katedra spojov, Univerzitná 8215/1, 01026 Žilina, Slovenská republika, tel.: +421 41513 3144, fax: +421 41565 5615, e-mail: Peter.Kolarovszki@fpedas.uniza.sk
} 
balíkový triedič so sklopnými plošinkami, ktorého princíp činností je popísaný v nasledujúcej podkapitole.

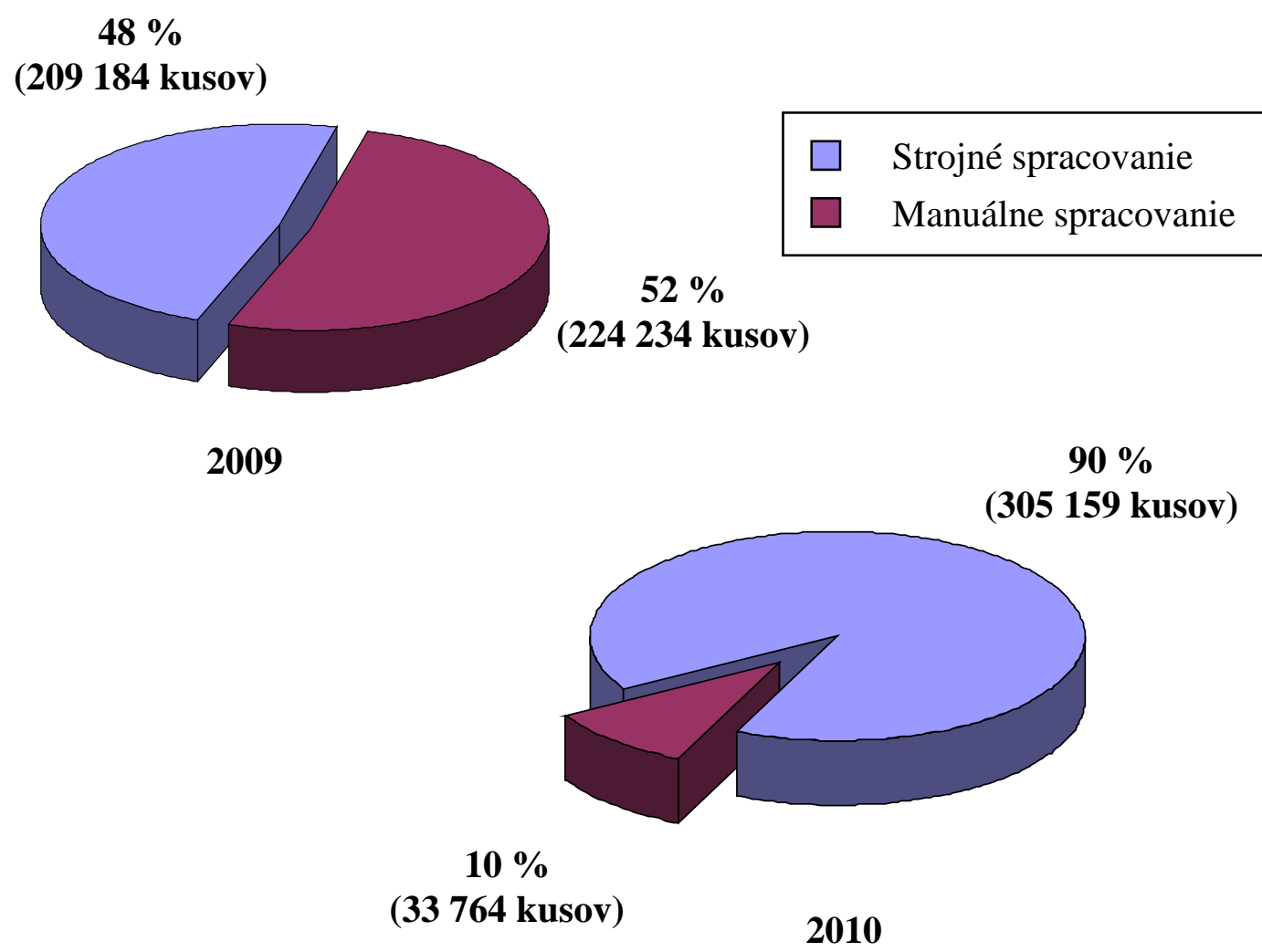

Obrázok 1. Počet spracovaných balíkov za prvé tri mesiace v rokoch 2009 a 2010

\subsection{Princíp činnosti balíkového triediaceho zariadenia}

\section{Technické údaje}

Triediace zariadenie sa skladá z:

- 2 vstupných pracovísk,

- 1 plošinkového triediča,

- 28 ciel'ových sklzov z odberovými stolmi,

- 1 nultého sklzu.

Výkon triediaceho zariadenia je 4050 plošiniek / hod. 


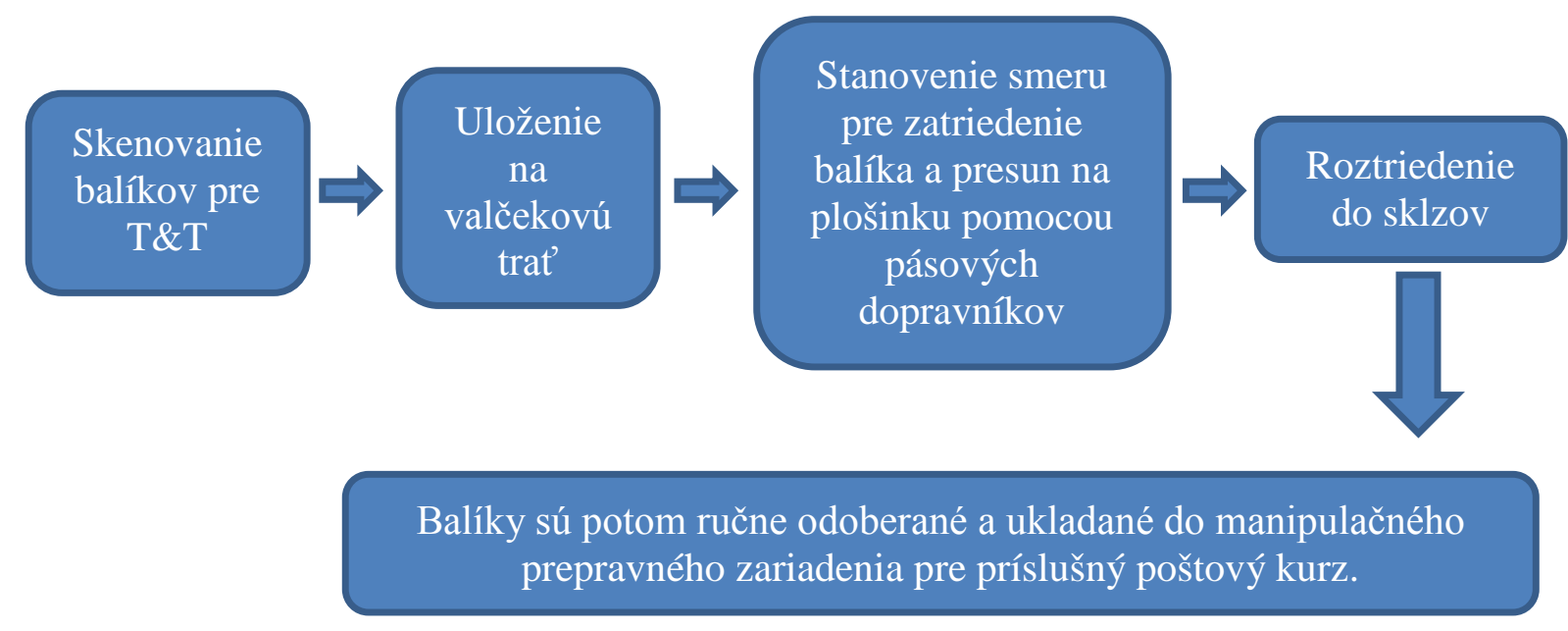

Obrázok 2. Princíp činnosti balíkového triediaceho zariadenia

\section{Postup triedenia pomocou ručne zadávaného PSČ na klávesnici}

Pracovník kladie balíky na valčekový dopravník tak, aby adresa s PSČ bola smerom hore, dlhšia strana balíku bola súbežná s pohybom dopravníkov a medzi balíkmi bola medzera minimálne $20 \mathrm{~cm}$. Balík prechádza z valčekového dopravníka M1 na kódovací dopravník M2, kde sa zastaví. Druhý pracovník pomocou špeciálnej klávesnice opíše PSČ z balíka a tlačidlom ENTER kódovanie ukončí. Na základe PSČ je balíku pridelené číslo, ktoré hovorí o tom, do ktorého sklzu má byt' balík zhodený. Balík odchádza na dopravník M3, kde sa zastaví a a počas čakania na príchod plošiny vertikálneho dopravníka M4-NERAK zároveň odváži digitálnou váhou.

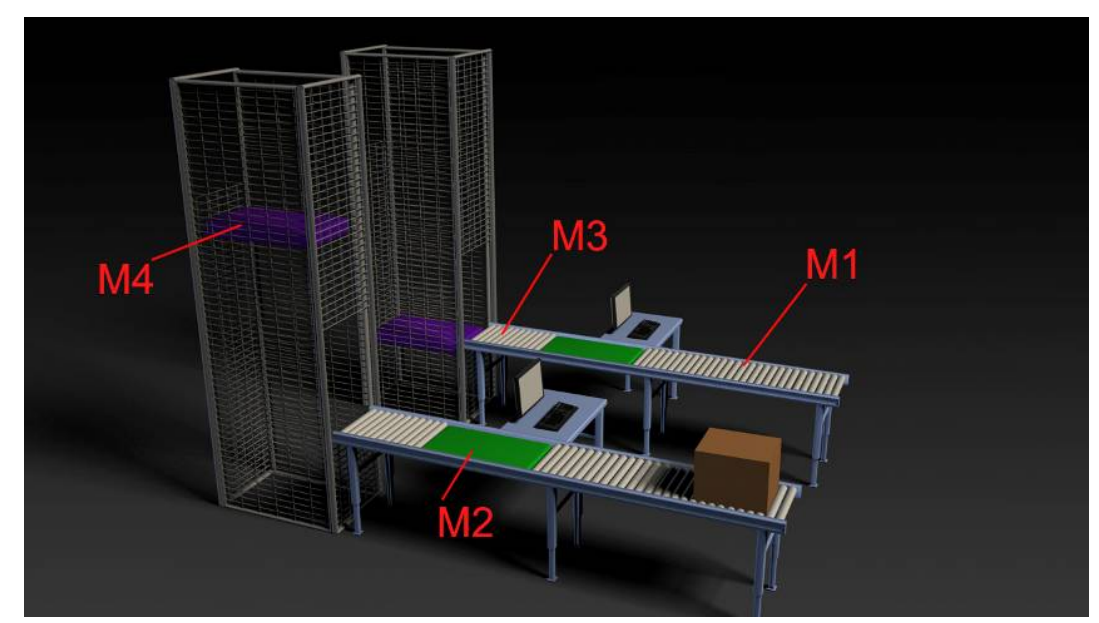

Obrázok 3. Systém dopravníkov vstupného pracoviska (3D model)

Pri prejazde balíku cez dopravníky M2 a M3 sa zároveň vykonáva meranie dížky balíku a na dopravníku M3 tiež výšky balíka. V prípade, že je niektorý z rozmerov väčší ako povolený, pás sa zastaví a balík je nutné vyradit' zo strojového triedenia. Pri tom sa na displeji vypíše hlásenie "DLHY BALÍK" alebo "VYSOKY BALÍK". Ak je balík na dopravníku M3 dlhý i vysoký vypíše sa iba hlásenia "VYSOKY BALÍK". Ked' sú namerané vel'kosti balíka v poriadku, balík prechádza do vertikálneho dopravníka M4, pokračuje d’alej na výstupný dopravník M5, prechádza zatáčkou M6 až na koniec synchronizačného dopravníka M7 kde sa opät' zastaví (obr. 4). 


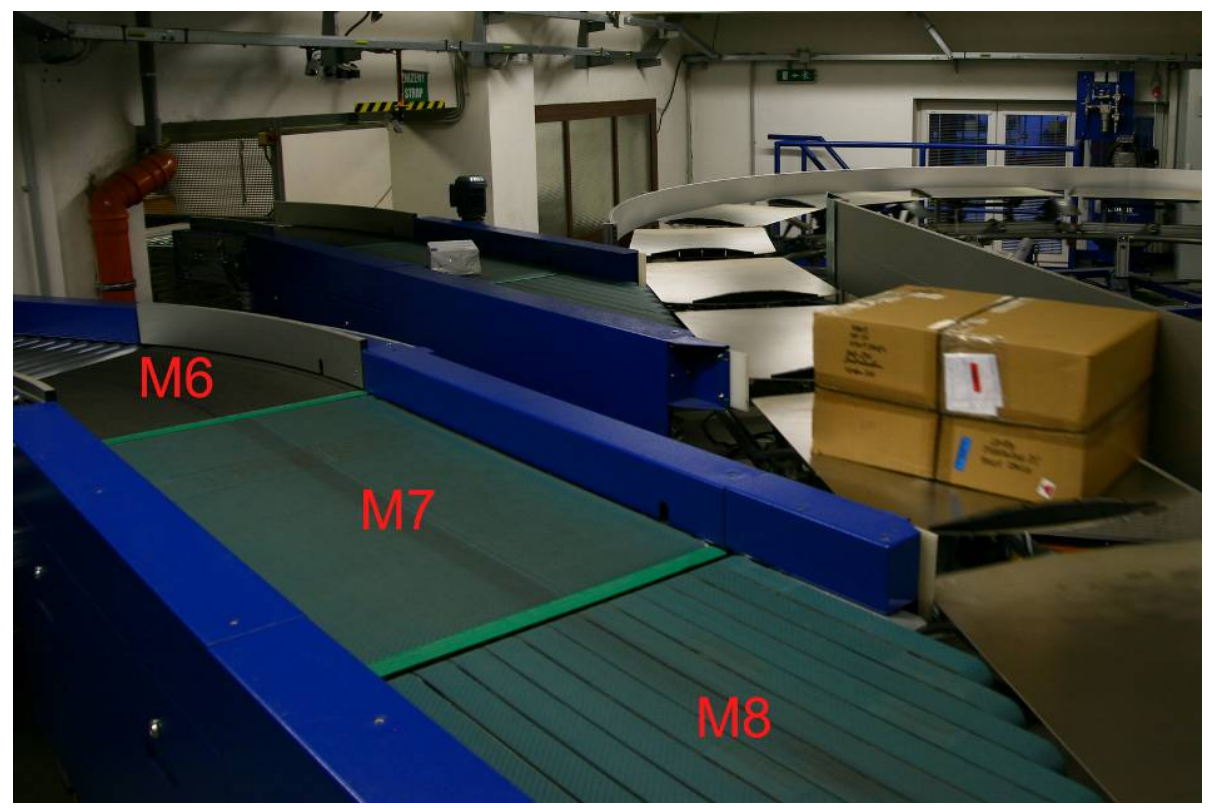

Obrázok 4. Systém synchronizačných a odovzdávacích dopravníkov

Riadiaci systém stroja nájde vol’nú plošinku, priradí ju k balíku a následne pomocou odovzdávacieho dopravníka M8 balík naloží na plošinku a odchádza k triedeniu. Plošinky s balíkmi prechádzajú okolo sklzov. Riadiaci systém stroja porovnáva číslo hlavného výstupu $\mathrm{s}$ číslom sklzu, pred ktorým sa plošinka s balíkom práve nachádza. Ak sa zistí zhoda, je balík zhodený a schádza sklzom na stolík pod ním. V prípade, že je daný sklz zaplnený (je zatienená fotobunka sklzu), zablokovaný tlačidlom umiestneným na stlípe u príslušného sklzu, alebo je zablokovaný z počítača dispečera, balík sa nesklopí, prechádza d'alej a bude zhodený pri d'alšom obehu. Zablokovanie sklzu je indikované rozsvietenou žiarovkou na stĺpe u príslušného sklzu. Ak počet obehov balíku dosiahol hodnoty nastavené dispečerom a balík predsa nemohol byt' zhodený do správneho sklzu, je balík spustený do vyhradeného sklzu 0 . V prípade, že obsluha zadá chybné PSČ je balík spustený do vyhradeného sklzu 27.

\section{Postup triedenia pomocou automatického kódovania stacionárnym skenerom}

Tento spôsob triedenia umožňuje triedit' balíky plynulo pomocou čiarových kódov snímaných stacionárnym skenerom (obrázok 5.), bez manuálneho kódovania PSČ na vstupnom pracovisku. Informácie obsiahnuté v čiarovom kóde a v databáze systému budú do systému vkladané pomocou elektronického podacieho hárku. Ten vyplní zákazník cez internet alebo prinesie na poštu spolu s balíkmi na CD nosiči.

Proces triedenia je $\mathrm{v}$ podstate rovnaký ako pri triedení pomocou ručného zadávania PSČ avšak po presunutí balíka na triediacu plošinku a jeho prechode pod stacionárnom skenerom je nasnímaný čiarový kód, podl’a ktorého je v databáze nájdené PSČ a v triediacej tabul'ke hlavný a náhradný výstup (sklz), do ktorého bude balík vytriedený. Ak nebol čiarový kód správne prečítaný alebo bol poškodený, je balík vytriedený do sklzu 0. Ak sa čiarový kód prečítal správne, ale $\mathrm{v}$ databáze nie sú dáta $\mathrm{k}$ tomuto prečítanému čiarovému kódu, alebo nie sú dáta $\mathrm{v}$ triediacej tabul'ke, balík je vytriedený do sklzov označených v triediacej tabul'ke ako "sklz pre balíky bez dát" a „sklz pre balíky, ktoré nie sú v triediace tabul'ke. 


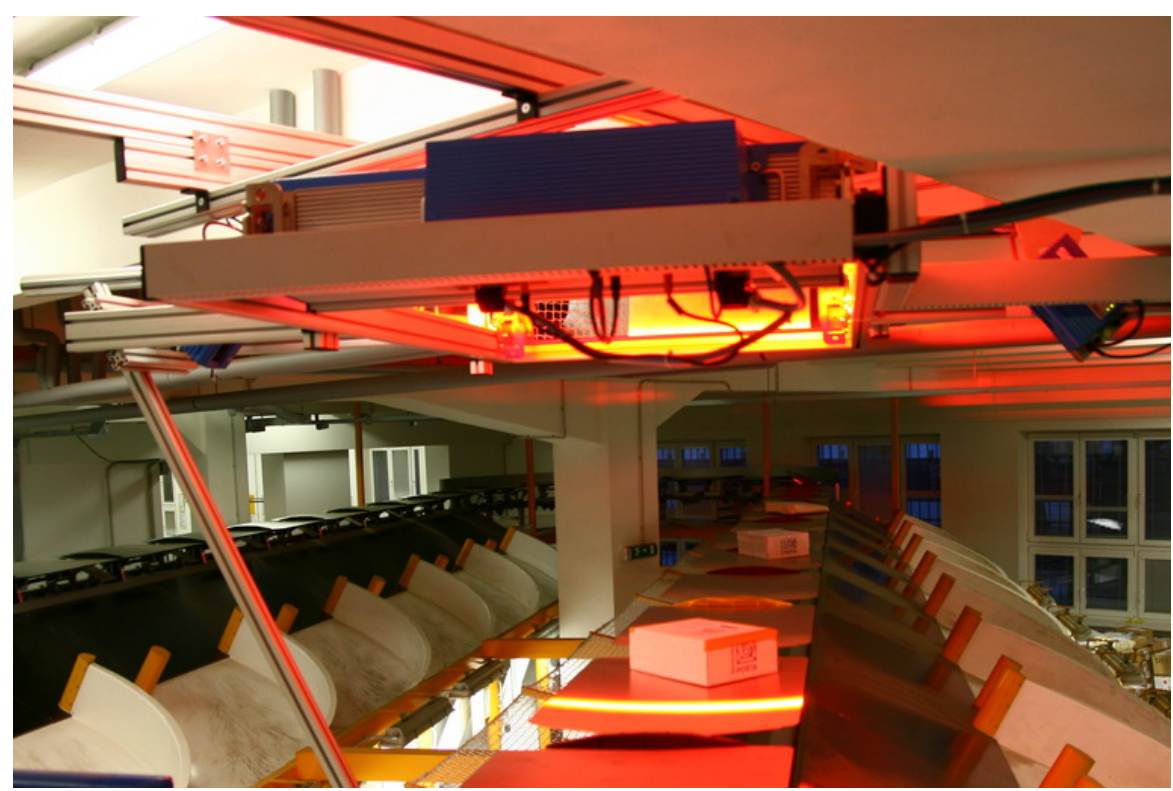

Obrázok 5. Stacionárny skener čiarových kódov

\section{Multimediálne spracovanie vybraných zariadení}

Pri každom multimediálnom diele je nevyhnutná podrobná príprava a rozplánovanie jednotlivých fáz tvorby. V tejto kapitole si ukážeme čast' multimediálnej aplikácie (3D modely liniek), ktoré boli použité vo výsledných aplikáciách. Hotové aplikácie je možné prezentovat' na vyžiadanie. [2]

\subsection{Príprava tvorby multimediálneho diela}

Najdôležitejšou čast'ou prípravy multimediálnej aplikácie je tvorba scenára, podl'a ktorého sa bude postupovat'.

\section{Scenár tvorby:}

- prvotný nápad - námet na vytvorenie multimediálneho diela,

- získanie potrebných podkladových materiálov: informácie, fakty pre tvorbu obrazového scenára, tvorbu 3D objektov,

- napísanie obrazového scenára pre video zložku a animácie,

- natočenie scén, ich editácia, strih, prípadné znovu natočenie,

- tvorba grafiky, 3D animácii,

- príprava textov popisujúcich jednotlivé funkčné bloky stroja ,

- vytvorenie užívatel'ského prostredia: poskladanie diela zo všetkých jeho častí - obraz zvuk - animácia - text, a finálna korekcia medzi nimi. [1]

\subsection{Ukážky multimediálneho diela}

Kompletná tvorba 3D modelov a animácií bola realizovaná v programe Maxon Cinema 4D. Cinema 4D je komplexný program pre tvorbu 3D grafiky.

\section{Balíkové triediace zariadenie:}

V snahe vytvorit' čo najjednoduchší a najprehl'adnejší 3D model balíkového triediaceho zariadenia bolo použitých čo najmenej druhov jednoduchých a jednofarebných textúr bez vzorov. Na konštrukcie dopravníkov bola aplikovaná textúra svetlomodrej farby, pričom na pás každého dopravníka je použitá textúra inej farby pre ich názorné oddelenie. [2] 


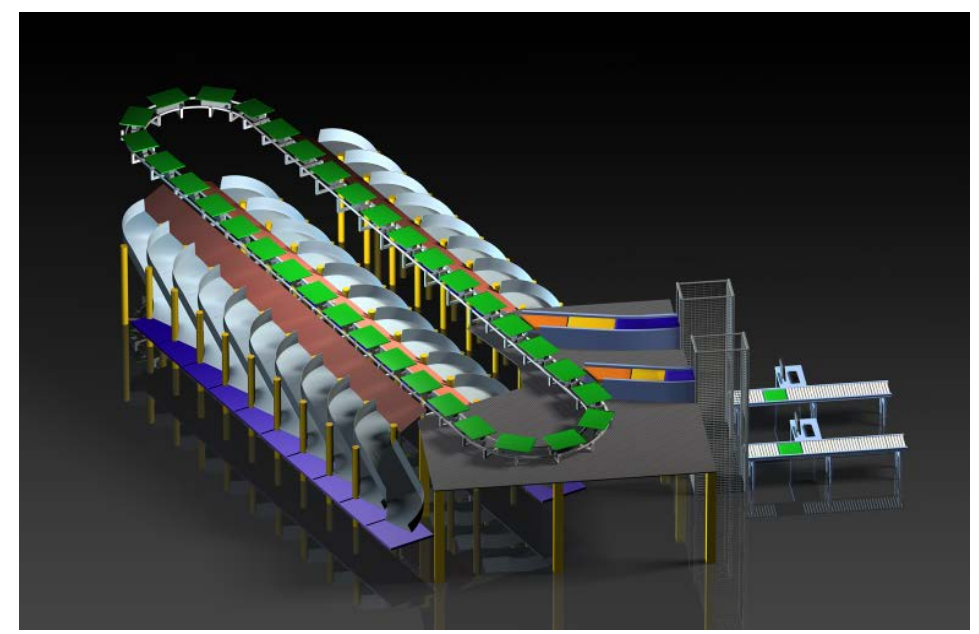

Obrázok 6. Výsledná scéna balíkového triediča

Z hl'adiska ucelenosti multimediálneho diela bola zrealizovaná 3D animácia, ktorá začína príchodom poštového kurzu na HSS 022 Žilina, s následným vykladaním balíkov a rozdelením na vhodné a nevhodné pre strojné spracovanie (obrázok 7.). Ďalšou častou aplikácie je výsledná scéna balíkového triediaceho zariadenia, kompletný postup triedenia na tomto zariadení. Pre názornú ukážku vid’ obrázok 6.

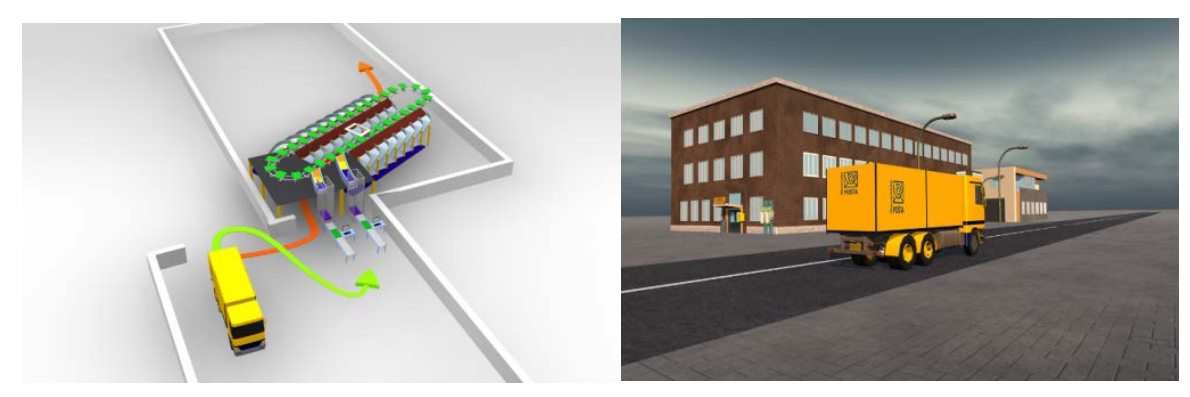

Obrázok 7. Vykladanie kurzu a model úvodnej animácie [2]

Výsledný produkt - Multimediálne spracovanie balíkového triediaceho zariadenia sa nachádza na Katedre spojov, konkrétne v NF 407 a je k dispozícii k nahliadnutiu. Po spustení súboru s príponou .exe sa prehrajú úvodné titulky a zobrazí sa sekcia Úvod, v ktorej sa nachádzajú základné informácie o aplikácii a balíkovom triediacom stroji. Z položiek menu si je možné l'ubovol'ne vybrat' d’alšie sekcie - Automatická prezentácia, Manuálna prezentácia, Parametre stroja a Fotogaléria. Každá pristupuje k informáciám o procese strojového triedenia balíkov iným štýlom a je na užívatel’ovi aký si vyberie. Množstvo multimediálneho obsahu v aplikácií kladie väčšie nároky na počítač, na ktorom bude aplikácia užívaná. Nároky na diskovú kapacitu sú 126 MB.[1] 


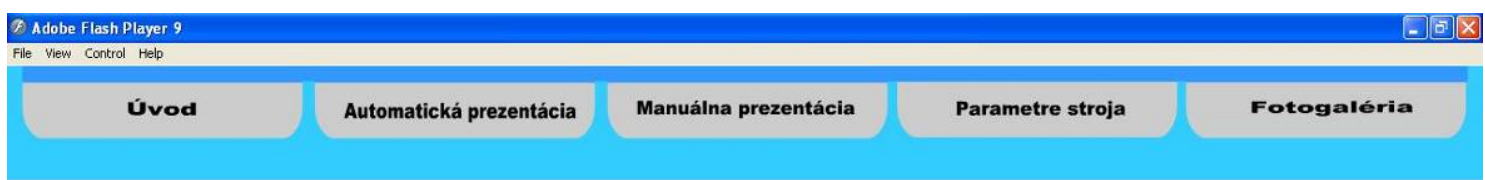

V roku 2009 bolo na HSS Žilina 022 nainštalované nové automatické balíkové triediace zariadenie, ktoré vymenilo pôvodny Juhoslovanský poloautomatický triediaci stroj z roku 1984. Táto aplikácia je venovaná procesu triedenia balíkov na novom balíkovom triediacom stroji, pričom prostredníctvom multimédií opisuje činnost jeho jednotlivých častí. Automatická prezentácia obsahuje 11 minútové video celého procesu triedenia od príchodu poštového kurzu až po vytriedené balíky. V manuálnej prezentácii je možnost' prezriee’ si jednotlivé sekvencie podla vlastnej vol'by. V sekcii Parametre stroja sú základné technické parametre a informácie o triediacom zariadení.

Porovinurie pôvodinej a novej triediacej linho

$\begin{array}{lll} & \text { Pôvodná triediaca linka } & \text { Nová triediaca linka } \\ \text { Počet výstupov } & 12+1 & 26+2 \\ \text { Počet sstupov } & 1 & 2 \\ \text { Výkon } & 750 \text { zásielok } / \mathrm{h} & 2 \times 1500 \text { zásielok } / \mathrm{h} \\ \text { Min, rozmery zásielly } & >70 \mathrm{~mm} & >4 \mathrm{~mm} \\ \text { Snímanie zásielok } & - & \text { Automatické } \\ \text { Typ zásielok } & \text { Baliky } & \text { Baliky, ně́tandardné } \\ \text { Typp obalov } & \text { Papier } & \text { Papier, fólia, plast } \\ \text { Príkon } & 112,7 \mathrm{~kW} & 19,8 \mathrm{~kW} \\ \text { Poruchovost' } & 3 \times \text { ttýżdenne } & -\end{array}$

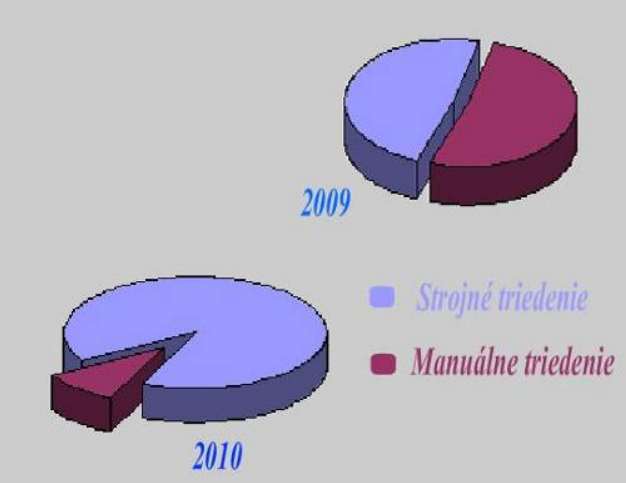

Obrázok 8. Užívatel’ské prostredie multimediálnej e-aplikácie.

\section{Záver}

Tradičné vyučovacie metódy a postupy nedokážu študentom sprostredkovat' tol'ko informácií, ako je to možné realizovat' využitím audiovizuálnych prostriedkov. Moderná výpočtová technika je súčast'ou didaktických pomôcok, ktoré pomáhajú skvalitňovat' vyučovací proces a pomáhajú pri uplatňovaní viacerých didaktických zásad, najmä názornosti, aktivity a uvedomelosti. Dnešné multimediálne technológie poukazujú na ich potenciál pri vzdelávaní. Multimediálne techniky prit’ahujú študentovu pozornost', čo umožňuje l'ahší a rýchlejší proces učenia. V súčasnosti sa na výučbu študentov v rámci predmetov zameraných na oblast' vel'kej mechanizácie a automatizácie poštového a logistického sektora ako aj automatickej identifikácie, využívajú powerpointové prezentácie, ktoré síce $\mathrm{v}$ sebe zahŕňaj klasické 2D obrázky avšak pre poskytnutie reálnej predstavy skúmanej problematiky je to pre potreby študentovi nepostačujúce. Je nutné aby si študent vedel predstavit’ príslušné zariadenie, proces alebo súhrn procesov nasledujúcich za sebou, čo je práve možné docielit' prostredníctvom vytvorenia príslušnej 3D počítačovej animácie. Pri prepojení tejto animácie $\mathrm{s}$ videozáznamom $\mathrm{z}$ reálneho prostredia je možné vytvorit' interaktívnu multimediálnu aplikáciu pri ktorej si študent bude môct' zvolit', či chce prejst' na príslušnú video sekvenciu alebo pokračovat' $\mathrm{v}$ animácii s príslušným výkladom učiva, ktorý bude zabezpečený formou textových titulkov.

Je dôležité podotknút', že funkcia pedagóga nezostane v úzadí, práve naopak, pedagóg svojím výkladom bude vhodne doplńnat príslušnú multimediálnu aplikáciu o svoje poznatky k prednášanej problematike a to formou komentáru. 
Multimediálne diela sú dôležitou súčast'ou vzdelávacieho procesu. Umožňujú dosiahnut' interaktivitu pre študentov, ktorý si vedia daný proces, jednoduchšie predstavit' a pochopit'. $Z$ pohl'adu poštového podniku, je možné multimediálne diela využívat' pri zaúčaní brigádnikov, ktorý s príslušnými zariadeniami prichádzajú do kontaktu. Tak isto je ich možné použit' aj na propagáciu svojej činnosti a tým prispiet' k bližšiemu povedomiu l'udí o pošte a jej procesoch.

\section{Literatúra}

[1] LACÍK, L. Multimediálne spracovanie vybraného balíkového triediaceho zariadenia [magisterská_inžinierska práca]; Škol. Peter Kolarovszki. - Žilina; 2010. - 70 s.

[2] VACULÍK, J., ACHIMSKÝ, K., MADLEŇÁK R. Multimédiá: spracovanie textu, fotografia, filmová technika a práca so zvukom /. - 1. vyd. - V Žiline : Žilinská univerzita, 2006. - 252 s., ilustr., tab. + 1 CD-ROM. - ISBN 80-8070-604-2.

[3] KOENIGSMARCK, A., Cinema 4D R10. Computer Press, 2008. ISBN: 978-80-2512056-9.

[4] SÁDOVSKy, E. Cinema 4D - Modelovanie I.. 2007. [online]. Grafika, 2007. [cit. 201004-10]. Dostupné na internete: < http://grafika.sk/clanok/cinema-4d-modelovanie-i/ >

[5] MADLEŇÁK R., VACULÍK J.: Elektronické podnikanie, odborná knižná publikácia, EDIS 2008, ISBN 978-80-8070-952-5

\section{Grantová podpora}

Tato štúdia/publikácia vznikla vd'aka podpore v rámci operačného programu Výskum a vývoj pre projekt:

Centrum excelentnosti pre systémy a služby inteligentnej dopravy II., ITMS 26220120050 spolufinancovaný zo zdrojov Európskeho fondu regionálneho rozvoja.

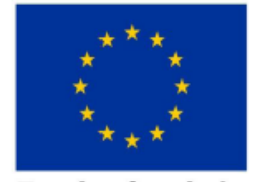

Európska únia

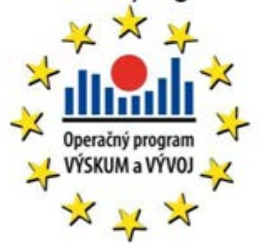

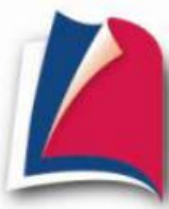

Agentúra

Ministerstva školstva, vedy, výskumu a športu SR pre štrukturálne fondy EÚ

"Podporujeme výskumné aktivity na Slovensku/Projekt je spolufinancovaný zo zdrojov EÚ" 